Research Article

\title{
Association of ABO Blood Group and Body Mass Index: A Cross-Sectional Study from a Ghanaian Population
}

\author{
Samuel Smith, ${ }^{1}$ Isaac Okai $\mathbb{D},{ }^{2}$ Chrissie Stansie Abaidoo, ${ }^{2}$ and Emmanuel Acheampong $\mathbb{B D}^{3}$ \\ ${ }^{1}$ Department of Medical Laboratory Technology, Kwame Nkrumah University of Science and Technology (KNUST), \\ Kumasi, Ghana \\ ${ }^{2}$ Department of Anatomy, School of Medical Sciences, Kwame Nkrumah University of Science and Technology (KNUST), \\ Kumasi, Ghana \\ ${ }^{3}$ Department of Molecular Medicine, School of Medical Sciences, Kwame Nkrumah University of Science and Technology \\ (KNUST), Kumasi, Ghana
}

Correspondence should be addressed to Isaac Okai; okabs2002@yahoo.com

Received 11 September 2017; Revised 21 December 2017; Accepted 15 February 2018; Published 18 March 2018

Academic Editor: C. S. Johnston

Copyright (C) 2018 Samuel Smith et al. This is an open access article distributed under the Creative Commons Attribution License, which permits unrestricted use, distribution, and reproduction in any medium, provided the original work is properly cited.

\begin{abstract}
$\mathrm{ABO}$ blood group and body mass index (BMI) have individually been appraised as risk factors for certain diseases. From statistical perspective, it may be important to examine the relationship between the ABO blood antigen and BMI. This cross-sectional study involved 412 participants aged 18 to 46 at the Kwame Nkrumah University of Science and Technology (KNUST), Kumasi. Weight and height of participants were measured for BMI calculation; blood group determination was done using antisera. Blood group $\mathrm{O}$ was the most prevalent (51.2\%), while Rhesus-positive individuals constituted $90.3 \% .6 .3 \%$ of the participants were obese, while $18.7 \%$ were overweight. There was significant $(p=0.006)$ higher prevalence of obesity in females $(10.3 \%)$ than in males $(3.4 \%)$. The study did not observe any significant difference by association of ABO blood group with gender $(p=0.973)$, BMI $(p=0.307)$, or Rhesus status $(p=0.723)$. Regarding gender $(p=0.400)$ and BMI $(p=0.197)$, no statistically significant difference was observed between Rhesus blood groups. The prevalence of overweight, obesity, blood type $\mathrm{O}$, and rhesus positive observed among students in this study is largely similar to what has been reported in published studies in Ghana and from other countries. Overweight and obesity were not associated with $\mathrm{ABO}$ blood groups or Rhesus in this study.
\end{abstract}

\section{Introduction}

The distribution pattern of the $\mathrm{ABO}$ blood antigen varies by the prevalence type among different populations in the world. The association between $\mathrm{ABO}$ blood group and several elements of the human population such as intelligence [1], socioeconomic status [2], diet [3], diseases [4], and others has long been suggested. Some of these reports such as from Gibson et al. [1] and Beardmore and KarimiBooshehri [2] linking $\mathrm{ABO}$ blood type to intelligence and socioeconomic class, respectively, have been decades old, and the potential mechanism by which $\mathrm{ABO}$ antigens determine these consequences was not underscored. Furthermore, D'Adamo's [3] popular blood type diet, without proven scientific evidence, was theoretically based on the belief that each $\mathrm{ABO}$ blood group carries the genetic information of their diets [5]. Thus, Cusack et al. [5] in a systematic review of published data on blood type diet concluded that there was no scientific proof to assess the effectiveness of the blood type diet. The authors recommended a validation study for the purported health benefits of blood type diets. From this premise, Wang et al. [6] conducted the first study to examine the association between blood type diets and biomarkers of cardiometabolic health in experimental and control groups. They concluded that some benefits that may be derived from adherence to the one's blood type diet are not directly attributable to the individual's $\mathrm{ABO}$ blood status; therefore, blood type diet hypothesis is not valid scientifically.

Nonetheless, the relationship between certain diseases and $\mathrm{ABO}$ blood type probably appears to have received good attention over the past five decades. Some reports have 
shown evidence of potential association between ABO blood and some diseases. However, it has yet to be fully established the validity or otherwise of how the statistical associations between blood group and some disease risks actually translate in vivo; evidence suggests that blood group antigens may play a biological role in some disease pathogenesis [7]. ABO antigen type has been postulated from many reports as a risk factor for some cardiovascular diseases [8-10], cancers [11-14], and infectious diseases [15-17]. The proposed mechanism believed to underlie how $\mathrm{ABO}$ blood group may influence cardiovascular disease risk involves the possible regulatory effect of $\mathrm{ABO}$ antigens on plasma levels of von Willebrand factor (VWF) and coagulation factor VIII (FVIII) $[18,19]$. This mechanism is corroborated by the observation that individuals with non-O blood group have circulating levels of both VWF and FVIII that are approximately $25 \%$ higher than those in $\mathrm{O}$ blood group subjects [18]; the presence of $\mathrm{ABH}$ antigenic structures on circulating VWF modulates their activity through specific glycosyltransferase enzymes [20]. Considering malignancies, the exact mechanism by which the $\mathrm{ABO}$ blood antigen may function in cancer pathogenesis is generally not known; however, one theory suggests that circulating levels of several proinflammatory and adhesion molecules which play a key role in the tumorigenesis process may be regulated by ABO blood antigens [21].

Body mass index (BMI), a measure of excess body weight, is useful for assessing aspects of health in children and adults within a population. Based on the WHO classification of BMI, an individual may be clinically considered obese, overweight, normal, or underweight. BMI pattern of distribution differs within and between different populations globally; changing trends in BMI of individual populations are known and linked to changes in socioeconomic status $[22,23]$. Obesity and overweight are known to be harmful to health [24], and many studies have demonstrated the association of increased BMI and risk of development of certain diseases. Excess body weight is believed to accentuate the risk of numerous diseases and clinical disorders, such as coronary heart disease, strokes, cancers, type 2 diabetes mellitus, hypertension, asthma, liver disease, psychopathological conditions [25], and allergic diseases [26].

Although ABO blood group and BMI have individually been appraised as risk factors for certain illnesses, few studies [27-40] have been conducted to examine whether carrying a particular $\mathrm{ABO}$ blood antigen potentially predisposes one to higher body mass index. These studies, however, have arrived at different conclusions on whether ABO status associates or does not associate with BMI. Due to the racial and ethnic disparities existing among different people globally, population-based studies are relevant. To our knowledge, no study has been done to test the association of BMI and $\mathrm{ABO}$ blood group in a Ghanaian sample. Therefore, this study was undertaken to examine the distribution and association of these two risk factors in a Ghanaian setting.

\section{Methodology}

2.1. Study Design and Setting. This cross-sectional study was conducted in KNUST from April 2017 to May 2017 among undergraduate students. KNUST is a public university located in Kumasi in the Ashanti Region of Ghana. The main university campus, which is about 7 square miles in area, is situated about 8 miles $(13 \mathrm{~km})$ to the east of Kumasi. There are 6 halls of residence at the main campus. The university has about 40,000 undergraduate students and consists of 6 colleges.

2.2. Study Population and Subject Selection. Using a simple random sampling stratified by the 6 colleges, a total of 412 students from the first to the fourth academic years were recruited for the study which included 238 males and 174 females of ages 18-46 years. Individuals with physical deformities that influenced height such as short or amputated lower limbs, kyphosis, and scoliosis, as well as those with bleeding disorders, were excluded from the study.

2.3. Sample Size Determination. A total of 412 participants were recruited from a population of 40,000 students at KNUST using an assumed distribution response rate among the respondents at $50 \%$, at $95 \%$ confidence interval ( $z$-score 1.96). Using the Cochran formula [41], the minimum size required was 381; however, to accommodate a nonresponse rate of $10.0 \%$ and stronger statistical power and effect size, the sample size was projected to 412 students.

2.4. Anthropometric Measurement and ABO Blood Group Analysis. Weight of the students was measured in the upright position to the nearest $0.5 \mathrm{~kg}$ using a weight measuring scale (Seca, Hamburg, Deutschland). Height was measured without shoes to the nearest $0.1 \mathrm{~cm}$ with a Shahe stature meter (Shanghai, China). BMI was calculated based as weight in kilograms divided by the square of the height in metres $\left(\mathrm{kg} / \mathrm{m}^{2}\right)$. Blood samples were collected for ABO blood group analysis.

2.5. Categorization of BMI. BMI was classified according to the proposed criteria of the WHO [18], where BMI of the following values: $<18.5 \mathrm{~kg} / \mathrm{m}^{2}, 18.5-24.9 \mathrm{~kg} / \mathrm{m}^{2}$, $25-29.9 \mathrm{~kg} / \mathrm{m}^{2}$, and $\geq 30 \mathrm{~kg} / \mathrm{m}^{2}$, is categorized as underweight, normal weight, overweight, and obese, respectively.

2.6. Ethical Consideration. Ethical approval (Ref.: CHRPE/ $\mathrm{AP} / 231 / 17)$ for the study was obtained from the Committee on Human Research, Publication and Ethics (CHRPE) of the School of Medical Sciences (SMS), Kwame Nkrumah University of Science and Technology (KNUST). Participation was voluntary, and written informed consent was obtained from each participant. Respondents were assured that the information gathered was to be used strictly for research and academic purposes only. In addition, respondents were given the freedom to opt out any time they thought they could not continue with the study.

2.7. Statistical Analysis. SPSS version 20.0 statistical software package was used to carry out statistical analysis. Descriptive 
statistics of the mean standard deviation and standard error was used to examine the data. Student's $t$-test for nonparametric data was used to compare the difference between the means of the two investigated parameters. The Pearson chi-square correlation analysis was used to determine the association between $\mathrm{BMI}$ and $\mathrm{ABO}$ blood group. Percentages for independent variables were calculated, and $p<0.05$ was considered statistically significant.

\section{Results and Discussion}

As shown in Table 1, of 412 students, $57.5 \%$ of the participants were male and $42.5 \%$ were female. The mean age was 23 years with the majority (70.0\%) of participants between 21 and 25 years. Blood group $\mathrm{O}$ was the most prevalent (51.2\%), followed by B (26.0\%), A (19.7\%), and AB (3.1\%). 90.3\% of individuals were Rhesus-positive, while 9.7\% were Rhesusnegative. Also, 6.3\% (26/412) of the participants were obese, while $18.7 \%$ (77/412) were overweight (Table 1).

Obesity was significantly $(p=0.006)$ prevalent among females $(10.3 \% ; 18 / 175)$ than males $(3.4 \% ; 8 / 237)$. The study did not observe any significant difference regarding the $A B O$ blood group in relation to gender, BMI, and Rhesus blood group (Table 2). Moreover, Rhesus status of participants was not significantly associated with either BMI or gender (Table 3). The prevalence of obesity and overweight observed in this study is similar to that of a cross-sectional study conducted among sampled students in Kumasi, Ghana, by Kumah et al. [42] but higher than that of Obirikorang et al.'s study [43]. Studies on overweight and obesity rates among students from other countries have demonstrated a wide variety of prevalence. For example, obesity and overweight rates were $10.4 \%$ among girls and 3.2\% among boys in Uganda and Ghana [44]. In Malaysia [45] and Pakistan [29], the rate among students was $14.8 \%$ and $16.0 \%$, respectively. However, studies carried out among public workers in Ghana had contrasting results [46]. It is possible that geographical and sample size differences may underlie the disparities in prevalence among the various reports. The high prevalence of overweight and obesity observed in females from our study is analogous to reports from studies by Kumah et al. [42] and Obirikorang et al. [43] in Ghana, Armstrong et al. [47] in South Africa, and Hamaideh et al. [48] in Jordan. In our cultural setting, overweight and obesity are seen as a sign of affluence and prosperity. As a result, most African women aspire to an increased BMI so as to be accepted. This cultural ideology is contrary to those of the western parts of the world who view females with a lower BMI to be more attractive. Additionally, males are naturally more active and tend to expend energy reserves as compared to females.

Blood type $\mathrm{O}$ was the prevalent $\mathrm{ABO}$ blood group in the present study. This trend of result is similar to the report from studies by Acquaye [49] in Ghana and Eru et al. [50] in Nigeria. Also, studies by Bhatti et al. [51] in India and Parveen et al. [30] as well as Bhattacharyya et al. [52] in Pakistan have reported similar ABO blood group pattern. Worldwide distribution pattern has shown blood type $\mathrm{O}$ to be the most prevalent blood group followed by group B, group $\mathrm{A}$, and group $\mathrm{AB}$ [53], which is consistent with the findings in this present study. Nonetheless, a study done among
TABle 1: Descriptive statistics of study participants $(n=412)$.

\begin{tabular}{|c|c|c|}
\hline Variables & Mean \pm SD & Percentage \\
\hline $\begin{array}{l}\text { Age (years) } \\
\text { Height }(\mathrm{cm}) \\
\text { Weight }(\mathrm{kg}) \\
\text { BMI }\left(\mathrm{kg} / \mathrm{m}^{2}\right)\end{array}$ & $\begin{array}{c}23.0 \pm 4.0 \\
169.8 \pm 8.6 \\
64.9 \pm 13.1 \\
22.5 \pm 4.0 \\
\end{array}$ & \\
\hline $\begin{array}{l}\text { Age groups (years) } \\
\leq 20 \\
21-25 \\
26-30 \\
>30\end{array}$ & $\begin{array}{c}\text { Frequency } \\
19 \\
280 \\
79 \\
31 \\
\end{array}$ & $\begin{array}{c}19.2 \\
70.0 \\
7.5 \\
5.3 \\
\end{array}$ \\
\hline $\begin{array}{l}\text { Gender } \\
\text { Male } \\
\text { Female }\end{array}$ & $\begin{array}{l}237 \\
175\end{array}$ & $\begin{array}{l}57.5 \\
42.5\end{array}$ \\
\hline $\begin{array}{l}\text { ABO blood groups } \\
\mathrm{A} \\
\mathrm{AB} \\
\mathrm{B} \\
\mathrm{O}\end{array}$ & $\begin{array}{c}81 \\
13 \\
107 \\
211\end{array}$ & $\begin{array}{c}19.7 \\
3.1 \\
26.0 \\
51.2\end{array}$ \\
\hline $\begin{array}{l}\text { Rhesus }(-/+) \\
\text { Negative } \\
\text { Positive }\end{array}$ & $\begin{array}{c}40 \\
372 \\
\end{array}$ & $\begin{array}{c}9.7 \\
90.3\end{array}$ \\
\hline $\begin{array}{l}\text { BMI categories } \\
\text { Underweight } \\
\text { Healthy } \\
\text { Overweight } \\
\text { Obese }\end{array}$ & $\begin{array}{c}49 \\
260 \\
77 \\
26\end{array}$ & $\begin{array}{r}11.9 \\
63.1 \\
18.7 \\
6.3\end{array}$ \\
\hline
\end{tabular}

SD : standard deviation; $n$ : number of participants.

a Turkish population found blood group A to be the most widely distributed [54]. Blood group $\mathrm{O}$ is hypothesized to offer the maximum protection to people who live in areas endemic for infectious diseases. Hence, the incidence of this blood group is very high in tropical regions of the world where infectious diseases are common [55]. The clinical importance of this distribution is illuminated by the low malaria parasitemia seen in individuals with the blood group $\mathrm{O}$ who live in West Africa [15].

Reports in literature on the relationship between $\mathrm{ABO}$ blood group and BMI are inconsistent $[38,56]$, with various authors associating increased BMI with the presence of particular $\mathrm{ABO}$ antigens, while others have shown no association between these two factors. Significant association was seen between $\mathrm{ABO}$ blood group and $\mathrm{BMI}$ among sampled populations from Pakistan [30], India [33, 34, 38], Malaysia $[31,32]$, Nigeria [35], and Denmark [40]. One may be tempted to assume that $\mathrm{ABO}$ blood type and body weight may be biologically related probably through a pathway that involves thrombotic factors like FVIII because it is known for example, that non-blood group $\mathrm{O}$ individuals have higher FVIII. For instance, increased BMI was associated with a higher level of FVIII [57, 58]. Also, obesity is considered to be an inflammatory disease [58], and this phenomenon may be linked to a hypothesized $\mathrm{ABO}$ blood antigen regulatory effect on inflammation [21]. Nevertheless, such a molecular pathway or any others have not been found, suggesting that association between $\mathrm{ABO}$ and $\mathrm{BMI}$ may be arbitrary.

The present study did not observe any significant association between $\mathrm{ABO}$ blood group and BMI. Our observation agrees with findings from large cross-sectional studies by 
TABLE 2: Association between ABO blood group and BMI, Rh blood group, and gender of the participants.

\begin{tabular}{|c|c|c|c|c|c|c|}
\hline \multirow{2}{*}{ Variables } & \multicolumn{4}{|c|}{ ABO blood group, $n(\%)$} & \multirow{2}{*}{$X^{2}, \mathrm{df}$} & \multirow{2}{*}{$p$ value } \\
\hline & $\mathrm{A}(n=81)$ & $\mathrm{AB}(n=13)$ & $\mathrm{B}(n=107)$ & $\mathrm{O}(n=211)$ & & \\
\hline \multicolumn{7}{|l|}{$B M I$} \\
\hline Underweight & $11(13.6 \%)$ & $3(23.1 \%)$ & $15(14.0 \%)$ & $20(9.5 \%)$ & $10.56,9$ & 0.307 \\
\hline Normal & $50(61.7 \%)$ & $8(61.5 \%)$ & $62(57.9 \%)$ & $140(66.4 \%)$ & & \\
\hline Overweight & $14(17.3 \%)$ & $0(0 \%)$ & $21(19.6 \%)$ & $42(19.9 \%)$ & & \\
\hline Obese & $6(7.4 \%)$ & $2(15.4 \%)$ & $9(8.4 \%)$ & $9(4.3 \%)$ & & \\
\hline$B M I($ mean $\pm S D)$ & $22.5 \pm 4.2$ & $22.4 \pm 5.2$ & $22.3 \pm 4.1$ & $22.5 \pm 3.8$ & & 0.964 (ANOVA) \\
\hline Rh blood group & & & & & $1.32,3$ & 0.723 \\
\hline Positive & $71(87.7 \%)$ & $12(92.3 \%)$ & $99(92.5 \%)$ & $190(90.0 \%)$ & & \\
\hline Negative & $10(12.3 \%)$ & $1(7.7 \%)$ & $8(7.5 \%)$ & $21(10.0 \%)$ & & \\
\hline Gender & & & & & $0.23,3$ & 0.973 \\
\hline Male & $45(55.6 \%)$ & $8(61.5 \%)$ & $62(57.9 \%)$ & $122(57.8 \%)$ & & \\
\hline Female & $36(44.4 \%)$ & $5(38.5 \%)$ & $45(42.1 \%)$ & $89(42.2 \%)$ & & \\
\hline
\end{tabular}

SD: standard deviation; $n$ : number of participants; $X^{2}$ : chi-square; df: degree of freedom; BMI: body mass index; ANOVA: analysis of variance; $p<0.05$ is statistically significant.

TABle 3: Association between Rh blood group and BMI and gender of the participants.

\begin{tabular}{|c|c|c|c|c|}
\hline \multirow{2}{*}{ Variables } & \multicolumn{2}{|c|}{ Rhesus blood group, $n$ (\%) } & \multirow{2}{*}{$X^{2}, \mathrm{df}$} & \multirow{2}{*}{$p$ value } \\
\hline & Negative $(n=40)$ & Positive $(n=372)$ & & \\
\hline Gender $^{\mathrm{a}}$ & & & & 0.400 \\
\hline Male & $26(65.0 \%)$ & $211(56.7 \%)$ & & \\
\hline Female & $14(35.0 \%)$ & $161(43.3 \%)$ & & \\
\hline$B M I\left(k g / m^{2}\right)^{\mathrm{b}}$ & & & $4.68,3$ & 0.197 \\
\hline Underweight & $4(10.0 \%)$ & $45(12.1 \%)$ & & \\
\hline Normal & $29(72.5 \%)$ & $231(62.1 \%)$ & & \\
\hline Overweight & $3(7.5 \%)$ & $74(19.9 \%)$ & & \\
\hline Obese & $4(10.0 \%)$ & $22(5.9 \%)$ & & \\
\hline
\end{tabular}

BMI: body mass index; $n$ : number of participants; $X^{2}$ : chi-square; df: degree of freedom; ${ }^{\mathrm{a}}$ Fisher's exact test; ${ }^{\mathrm{b}}$ chi-square test; $p<0.05$ is statistically significant.

Jafari et al. [28] among different ethnicities in Pakistan and other studies by Aboel-Fetoh et al. [27] in Saudi Arabia, Ainee et al. [39] in Sargodha District, Chuemere et al. [36] in Nigeria, and Mascie-Taylor and Lasker in the UK [37]. The absence of any significant association between ABO and BMI in our study may not be surprising as even larger cohort studies like those by Jafari et al. [28] and MascieTaylor and Lasker [37] failed to link BMI with either ABO or $\mathrm{Rh}$ phenotype. Furthermore, to our knowledge, it is not established from any genome-wide association studies in literature whether some genes such as FTO, LEP, LEPR, $M C 4 R, N P Y 2 R$, and POMC that have been implicated in higher $\mathrm{BMI}$ are located on the same chromosomal region as that of $\mathrm{ABO}$ or that $\mathrm{ABO}$ gene exerts regulatory control over them. It is therefore plausible to say that a genetic basis for linking $\mathrm{ABO}$ to $\mathrm{BMI}$ is sufficiently lacking. In our opinion, the different observations made regarding the relationship between $\mathrm{ABO} / \mathrm{Rh}$ status and BMI may be practically dependent on local factors that modify population phenotype [37] or sample size variation rather than actual genetic influence. Collectively, our findings are comparable to reports from other studies [27, 28, 39, 42-51]. However, being an institutional-based cross-sectional study, we recognize that making generalization of our findings to the Ghanaian population may be inappropriate.

\section{Conclusion}

The prevalence of overweight, obesity, blood type $\mathrm{O}$, and Rhesus positive observed among students in this study is largely similar to what has been generally reported in literature. However, overweight and obesity were not associated with $\mathrm{ABO}$ blood groups or Rhesus in this study contrary to the view of some reports. There is the need for educational-based multiple strategies to combat the increasing rate of obesity and overweight among students.

\section{Conflicts of Interest}

The authors declare that there are no conflicts of interest regarding the publication of this paper.

\section{References}

[1] J. B. Gibson, G. Harrison, V. Clarke, and R. Hiorns, "IQ and ABO blood groups," Nature, vol. 246, no. 5434, pp. 498-500, 1973.

[2] J. Beardmore and F. Karimi-Booshehri, “ABO genes are differentially distributed in socio-economic groups in England," Nature, vol. 303, no. 5917, pp. 522-524, 1983.

[3] P. J. D’Adamo and P. D’Adamo, Eat Right 4 Your Type, Century, New York, NY, USA, 2002. 
[4] G. Garratty, "Relationship of blood groups to disease: do blood group antigens have a biological role," Revista Médica del Instituto Mexicano del Seguro Social Julio-Agosto, vol. 43, no. 1, pp. 113-121, 2005.

[5] L. Cusack, E. De Buck, V. Compernolle, and P. Vandekerckhove, "Blood type diets lack supporting evidence: a systematic review," American Journal of Clinical Nutrition, vol. 98, no. 1, pp. 99-104, 2013.

[6] J. Wang, B. García-Bailo, D. E. Nielsen, and A. El-Sohemy, "ABO genotype, 'blood-type' diet and cardiometabolic risk factors," PLoS One, vol. 9, no. 1, article e84749, 2014.

[7] G. Garratty, "Blood groups and disease: a historical perspective," Transfusion Medicine Reviews, vol. 14, no. 4, pp. 291-301, 2000.

[8] S. Biswas, P. K. Ghoshal, B. Halder, and N. Mandal, "Distribution of $\mathrm{ABO}$ blood group and major cardiovascular risk factors with coronary heart disease," BioMed Research International, vol. 2013, pp. 1-5, 2013.

[9] M. He, B. Wolpin, K. Rexrode et al., "ABO blood group and risk of coronary heart disease in two prospective cohort studies," Arteriosclerosis, Thrombosis, and Vascular Biology, vol. 32, no. 9, pp. 2314-2320, 2012.

[10] H. Wazirali, R. A. Ashfaque, and J. W. Herzig, "Association of blood group A with increased risk of coronary heart disease in the Pakistani population," Pakistan Journal of Physiology, vol. 1, no. 1-2, pp. 1-3, 2005.

[11] R. Aly, A. Yousef, and O. Elbably, "Association of ABO blood group and risk of breast cancer," Journal of Blood Disoders and Transfusion, vol. 5, no. 9, pp. 1-4, 2014

[12] M. A. Gates, M. Xu, W. Y. Chen, P. Kraft, S. E. Hankinson, and B. M. Wolpin, "ABO blood group and breast cancer incidence and survival," International Journal of Cancer, vol. 130, no. 9, pp. 2129-2137, 2012.

[13] Z. Wang, L. Liu, J. Ji et al., "ABO blood group system and gastric cancer: a case-control study and meta-analysis," International Journal of Molecular Sciences, vol. 13, no. 10, pp. 13308-13321, 2012.

[14] B. M. Wolpin, A. T. Chan, P. Hartge et al., "ABO blood group and the risk of pancreatic cancer," Journal of the National Cancer Institute, vol. 101, no. 6, pp. 424-431, 2009.

[15] R. Afoakwah, E. Aubyn, J. Prah, E. K. Nwaefuna, and J. N. Boampong, "Relative susceptibilities of ABO blood groups to Plasmodium falciparum malaria in Ghana," Advances in Hematology, vol. 2016, Article ID 536979, 4 pages, 2016.

[16] S. Kalayanarooj, R. V. Gibbons, D. Vaughn et al., "Blood group $\mathrm{AB}$ is associated with increased risk for severe dengue disease in secondary infections," Journal of Infectious Diseases, vol. 195, no. 7, pp. 1014-1017, 2007.

[17] B. Mohsenpour, K. Hajibagheri, S. Afrasiabian, E. Ghaderi, and S. Ghasembegloo, "ABO blood groups and susceptibility to brucellosis," Japanese Journal of Infectious Diseases, vol. 68, no. 2, pp. 124-127, 2015.

[18] P. V. Jenkins and J. S. O'Donnell, “ABO blood group determines plasma von Willebrand factor levels: a biologic function after all?," Transfusion, vol. 46, no. 10, pp. 1836-1844, 2006.

[19] J. Song, F. Chen, M. Campos et al., "Quantitative influence of ABO blood groups on factor VIII and its ratio to von Willebrand factor, novel observations from an ARIC study of 11,673 subjects," PLoS One, vol. 10, no. 8, article e0132626, 2015.

[20] M. Franchini, S. Crestani, F. Frattini, C. Sissa, and C. Bonfanti, "ABO blood group and von Willebrand factor: biological implications," Clinical Chemistry and Laboratory Medicine, vol. 52, no. 9, pp. 1273-1276, 2014.

[21] G. M. Liumbruno and M. Franchini, "Hemostasis, cancer, and ABO blood group: the most recent evidence of association," Journal of Thrombosis and Thrombolysis, vol. 38, no. 2, pp. 160-166, 2014.

[22] S. Subramanian, J. M. Perkins, E. Özaltin, and G. D. Smith, "Weight of nations: a socioeconomic analysis of women in low- to middle-income countries," American Journal of Clinical Nutrition, vol. 93, no. 2, pp. 413-421, 2011.

[23] S. Subramanian, J. E. Finlay, and M. Neuman, "Global trends in body-mass index," The Lancet, vol. 377, no. 9781, pp. 1915-1916, 2011.

[24] Obesity and Overweight, 2017, http://www.who.int/mediacentre/ factsheets/fs311/en/index.html.

[25] J. A. Knight, "Diseases and disorders associated with excess body weight," Annals of Clinical and Laboratory Science, vol. 41, no. 2, pp. 107-121, 2011.

[26] A. Irei, K. Takahashi, D. S. N. Le, P. Ha, and N. Hung, "Obesity is associated with increased risk of allergy in Vietnamese adolescents," European Journal of Clinical Nutrition, vol. 59, no. 4, pp. 571-577, 2005.

[27] N. M. Aboel-Fetoh, A. R. Alanazi, A. S. Alanazi, and A. N. Alruwili, "ABO blood groups and risk for obesity in Arar, Northern Saudi Arabia," Journal of the Egyptian Public Health Association, vol. 91, no. 4, pp. 169-173, 2016.

[28] E. Jafari, V. Sebghatollahi, S. Kolahdoozan, E. Elahi, and A. Pourshams, "Body mass index and ABO blood groups among different ethnicities of the Golestan cohort study subjects," Govaresh, vol. 17, no. 1, pp. 50-54, 2012.

[29] G. S. Krishnakanth, U. P. Lad, and P. Satyanarayana, "Correlation between obesity \& ABO blood group in school going children in India," Indian Journal of Basic and Applied Medical Research, vol. 1, no. 4, pp. 280-284, 2012.

[30] N. Parveen, J. Rehman, S. H. Hassan, Z. Hassan, and M. Rehman, "Different blood groups association with body mass index in medical students of Karachi," Professional Medical Journal, vol. 23, no. 8, pp. 1001-1004, 2016.

[31] K. Sukalingam and K. Ganesan, "Rhesus blood groups associated with risk to obesity and diabetes mellitus: a report on Punjabi population in Selangor, Malaysia," International Journal of Integrative Medical Sciences, vol. 2, no. 4, pp. 105109, 2015.

[32] Y. A. Qunq and A. Z. Abdel Hamid, "ABO blood group associations with obesity in random samples from Advanced Medical and Dental Institute staff and students," Biohealth Science Bulletin, vol. 4, no. 1, pp. 18-23, 2012.

[33] S. Behera, A. Sahoo, and P. Satyanarayana, "Relationship of blood group with body fat percentage, visceral fat, and waisthip ratio," National Journal of Physiology, Pharmacy and Pharmacology, vol. 6, no. 6, pp. 591-595, 2016.

[34] K. Ganesan and S. B. Gani, "Relationship between ABO, Rh blood groups and diabetes mellitus, obesity in Namakkal town, Tamilnadu," International Journal of Advances in Pharmacy, Biology and Chemistry, vol. 3, no. 4, pp. 995-998, 2014.

[35] F. C. Mmom and A. N. Chuemere, "Study of incidence and prevalence of hypertension, diabetes and obesity with blood type in postmenopausal females in Port Harcourt," Saudi Journal of Biomedical Research, vol. 1, no. 1, pp. 22-29, 2016.

[36] A. N. Chuemere, O. J. Olorunfemi, J. U. Nwogu, O. F. Mmom, E. O. Agbai, and V. V. Vurey, "Correlation between blood group, hypertension, obesity, diabetes, and combination of prehypertension and pre-diabetes in school aged children and 
adolescents in Port Harcourt," IOSR Journal of Dental and Medical Sciences, vol. 14, no. 12, pp. 83-89, 2015.

[37] C. Mascie-Taylor and G. Lasker, "Lack of an association between $\mathrm{ABO}$ and $\mathrm{Rh}$ blood group polymorphisms and stature, body weight, and BMI in a cohort of British women," Human Biology, vol. 62, no. 4, pp. 573-576, 1990.

[38] T. Chandra and A. Gupta, "Association and distribution of hypertension, obesity and ABO blood groups in blood donors," Iranian Journal of Pediatric Hematology and Oncology, vol. 2, no. 4, pp. 140-145, 2012.

[39] A. Ainee, S. Hussain, T. Kauser, T. M. Qureshi, M. Nadeem, and F. Rashid, "Studies on comparison of body mass index (BMI) of school going children having different blood groups (A, B, Ab and O) of Sargodha District," Pakistan Journal of Nutrition, vol. 13, no. 3, pp. 164-167, 2014.

[40] P. Suadicani, H. Hein, and F. Gyntelberg, "Airborne occupational exposure, $\mathrm{ABO}$ phenotype and risk of ischaemic heart disease in the Copenhagen Male Study," Journal of Cardiovascular Risk, vol. 9, no. 4, pp. 191-198, 2002.

[41] W. G. Cochran, Sampling Techniques-3, 1977.

[42] D. Kumah, K. Akuffo, J. Abaka-Cann, D. Affram, and E. Osae, "Prevalence of overweight and obesity among students in the Kumasi metropolis," Journal of Nutrition and Metabolism, vol. 2015, Article ID 613207, 4 pages, 2015.

[43] C. Obirikorang, E. Anto, P. Addai, Y. Obirikorang, and E. Acheampong, "Prevalence and risks factors of overweight/obesity among undergraduate students: an institutional based crosssectional study, Ghana," Journal of Medical and Biomedical Sciences, vol. 6, no. 1, pp. 24-34, 2017.

[44] K. Peltzer and S. Pengpid, "Overweight and obesity and associated factors among school-aged adolescents in Ghana and Uganda," International Journal of Environmental Research and Public Health, vol. 8, no. 10, pp. 3859-3870, 2011.

[45] M. S. Zalilah, G. Khor, K. Mirnalini, A. Norimah, and M. Ang, "Dietary intake, physical activity and energy expenditure of Malaysian adolescents," Singapore Medical Journal, vol. 47, no. 6, pp. 491-498, 2006.

[46] S. Adu-Afarwuah, A. Lartey, H. Okronipa et al., "Lipid-based nutrient supplement increases the birth size of infants of primiparous women in Ghana," American Journal of Clinical Nutrition, vol. 101, no. 4, pp. 835-846, 2015.

[47] M. Armstrong, M. Lambert, K. Sharwood, and E. Lambert, "Obesity and overweight in South African primary school children-the Health of the Nation Study," South African Medical Journal, vol. 96, no. 5, pp. 439-444, 2006.

[48] S. H. Hamaideh, R. Y. Al-Khateeb, and A. B. Al-Rawashdeh, "Overweight and obesity and their correlates among Jordanian adolescents," Journal of Nursing Scholarship, vol. 42, no. 4, pp. 387-394, 2010.

[49] J. Acquaye, "ABO, Rhesus and Kell blood groups in the Akans of Ghana," Ghana Medical Journal, vol. 38, no. 2, pp. 68-71, 2004.

[50] E. Eru, O. Adeniyi, and A. Jogo, “ABO and Rhesus blood group distribution among students of Benue State University Makurdi, Nigeria," African Journal of Biomedical Research, vol. 17, no. 1, pp. 49-52, 2014.

[51] R. Bhatti and D. Shiekh, "Variations of ABO blood groups. Gene frequencies in the population of Sindh (Pakistan)," Annals of King Edward Medical University, vol. 5, pp. 328-331, 1999.

[52] S. Bhattacharyya, B. Ganaraja, and R. Bhat, "Correlation between the blood groups, BMI and pre hypertension among medical students," Journal of Chinese Clinical Medicine, vol. 5, no. 2, pp. 78-82, 2010.
[53] Racial and Ethnic Distribution of ABO Blood Types 20032008, 2010, http://www.bloodbook.com/world-abo.html.

[54] I. Sari, O. Ozer, V. Davutoglu, S. Gorgulu, M. Eren, and M. Aksoy, "ABO blood group distribution and major cardiovascular risk factors in patients with acute myocardial infarction," Blood Coagulation and Fibrinolysis, vol. 19, no. 3, pp. 231-234, 2008.

[55] P. D'Adamo, Live Right for Your Type, Penguin Books, London, UK, 2001.

[56] Z. Slipko, B. Latuchowska, and E. Wojtkowska, "Body structure and $\mathrm{ABO}$ and $\mathrm{Rh}$ blood groups in patients with advanced coronary heart disease after aorto-coronary by-pass surgery," Polskie Archiwum Medycyny Wewnetrznej, vol. 91, no. 1, pp. 55-60, 1994.

[57] M. Abdollahi, M. Cushman, and F. R. Rosendaal, "Obesity: risk of venous thrombosis and the interaction with coagulation factor levels and oral contraceptive use," Thrombosis and Haemostasis, vol. 89, no. 3, pp. 493-498, 2003.

[58] D. R. Faber, P. G. de Groot, and F. L. Visseren, "Role of adipose tissue in haemostasis, coagulation and fibrinolysis," Obesity Reviews, vol. 10, no. 5, pp. 554-563, 2009. 


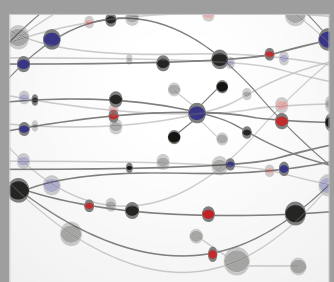

The Scientific World Journal
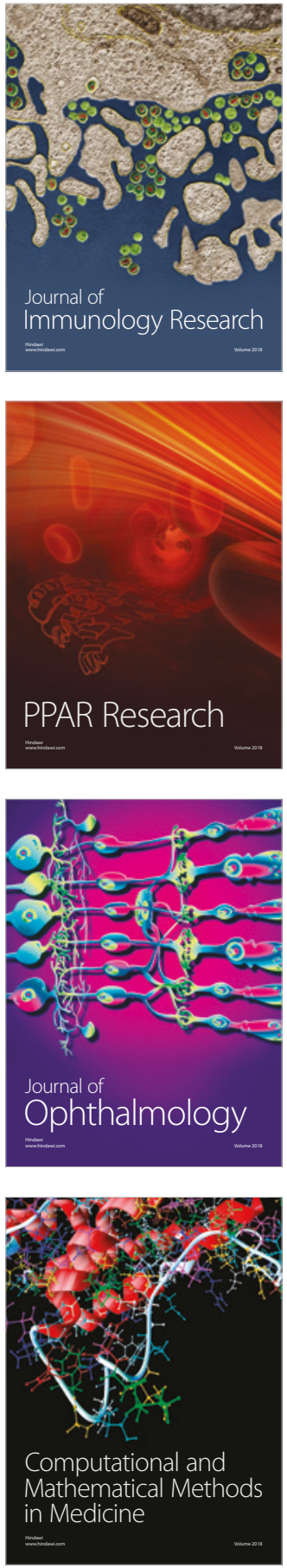

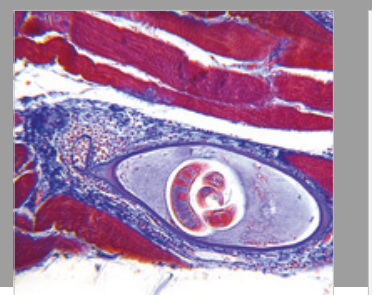

Gastroenterology Research and Practice

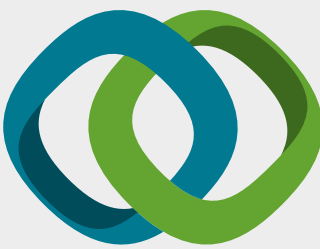

\section{Hindawi}

Submit your manuscripts at

www.hindawi.com
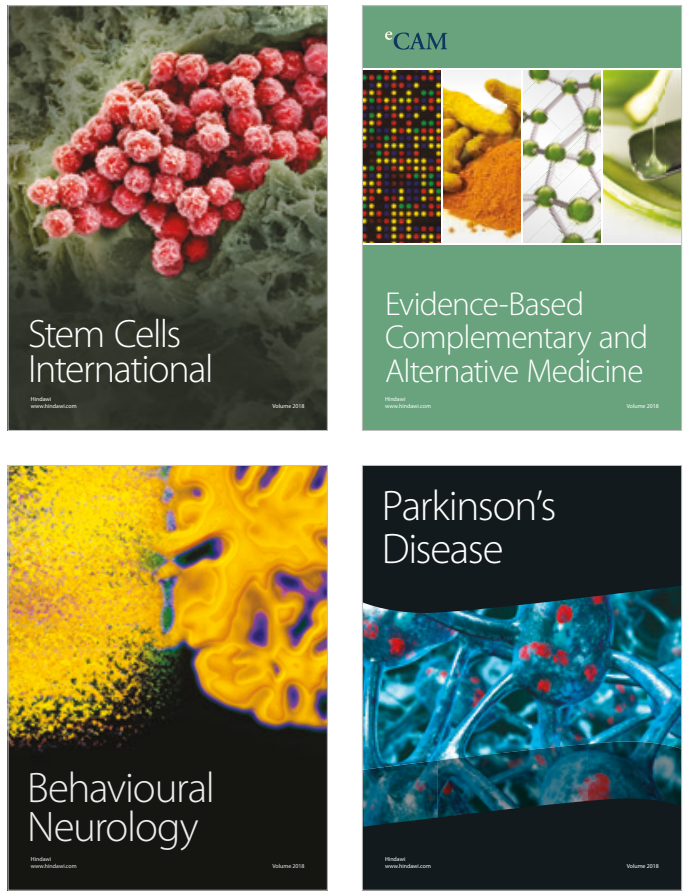

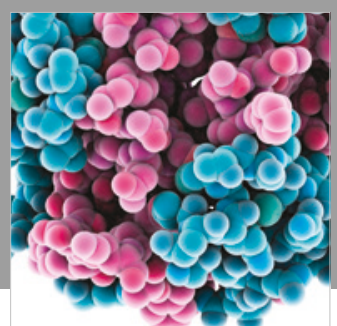

ournal of

Diabetes Research

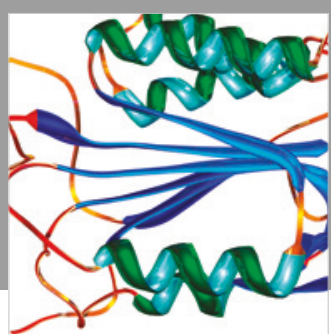

Disease Markers
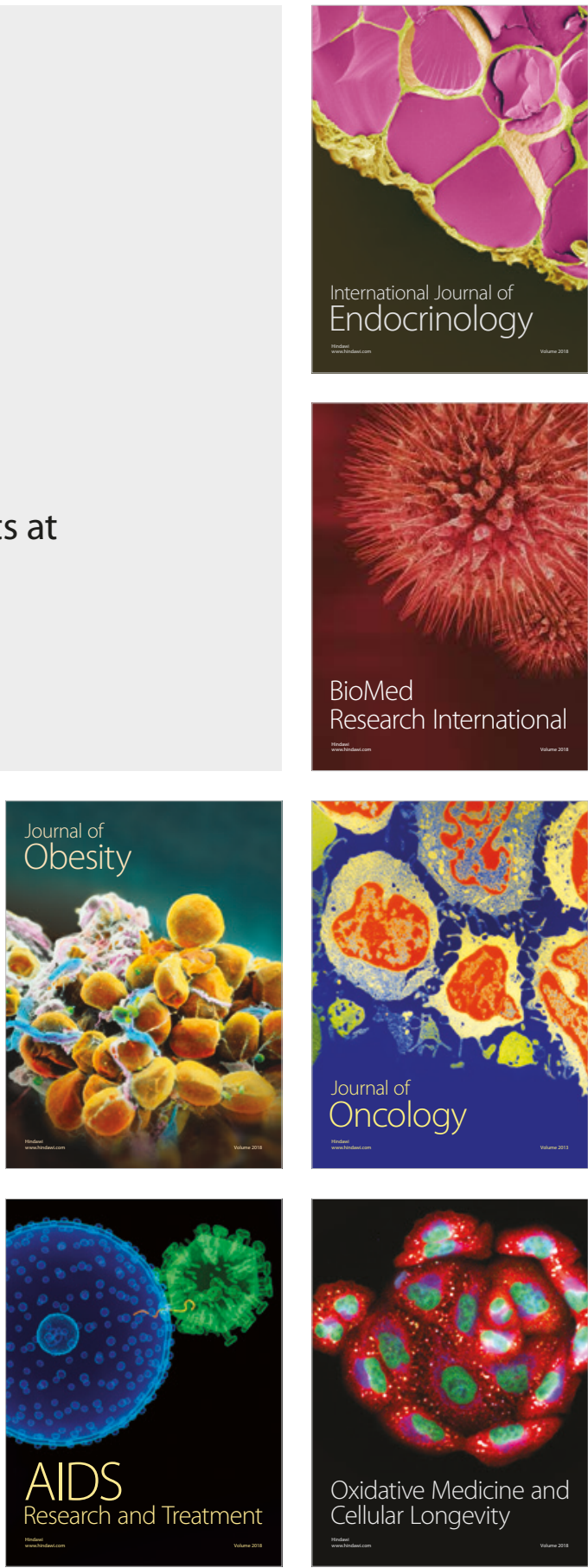